San Jose State University

SJSU ScholarWorks

Master's Theses

Master's Theses and Graduate Research

1993

\title{
Comparison of English reading and oral language production scores of students enrolled in two different bilingual education models
}

Jennifer Louise Hoag Daves

San Jose State University

Follow this and additional works at: https://scholarworks.sjsu.edu/etd_theses

\section{Recommended Citation}

Daves, Jennifer Louise Hoag, "Comparison of English reading and oral language production scores of students enrolled in two different bilingual education models" (1993). Master's Theses. 624.

DOI: https://doi.org/10.31979/etd.bsq5-795a

https://scholarworks.sjsu.edu/etd_theses/624

This Thesis is brought to you for free and open access by the Master's Theses and Graduate Research at SJSU ScholarWorks. It has been accepted for inclusion in Master's Theses by an authorized administrator of SJSU ScholarWorks. For more information, please contact scholarworks@sjsu.edu. 


\section{INFORMATION TO USERS}

This manuscript has been reproduced from the microfilm master. UMI films the text directly from the original or copy submitted. Thus, some thesis and dissertation copies are in typewriter face, while others may be from any type of computer printer.

The quality of this reproduction is dependent upon the quality of the copy submitted. Broken or indistinct print, colored or poor quality illustrations and photographs, print bleedthrough, substandard margins, and improper alignment can adversely affect reproduction.

In the unlikely event that the author did not send UMI a complete manuscript and there are missing pages, these will be noted. Also, if unauthorized copyright material had to be removed, a note will indicate the deletion.

Oversize materials (e.g., maps, drawings, charts) are reproduced by sectioning the original, beginning at the upper left-hand corner and continuing from left to right in equal sections with small overlaps. Each original is also photographed in one exposure and is included in reduced form at the back of the book.

Photographs included in the original manuscript have been reproduced xerographically in this copy. Higher quality 6" x 9" black and white photographic prints are available for any photographs or illustrations appearing in this copy for an additional charge. Contact UMI directly to order.

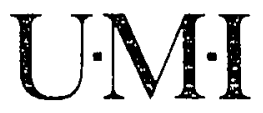

University Microfilms International

A Bell \& Howell Information Company 
Order Number 1354139

Comparison of English reading and oral language production scores of students enrolled in two different bilingual education models

Daves, Jennifer Louise Hoag, M.A.

San Jose State University, 1993

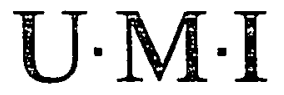

300 N. Zeeb Rd.

Ann Arbor, MI 48106 


\title{
COMPARISON OF ENGLISH READING AND ORAL IAANGUAGE PRODUCTION SCORES OF STUDENTS ENROLLED IN TWO DIFFERENT BILINGUAL EDUCATION MODELS
}

\author{
A Thesis \\ Presented to \\ The Faculty of the Department of Education \\ San Jose State University
}

In Partial Fulfillment

of the Requirements for the Degree

Master of Arts

By

Jennifer Louise Hoag Daves

August, 1993 


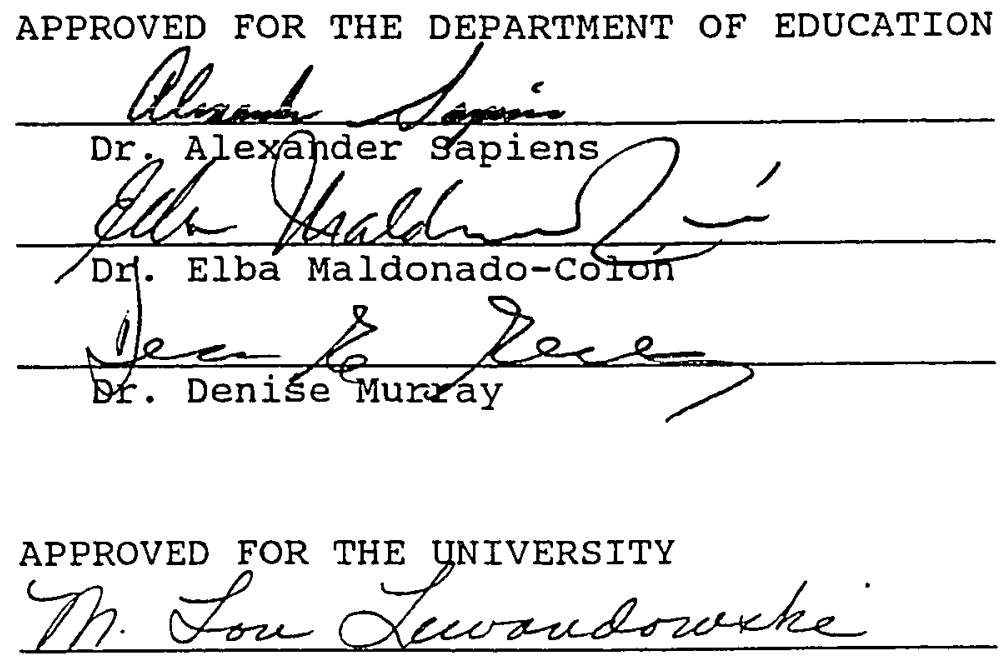




\begin{abstract}
Comparison of English Reading and Oral Language Production Scores of Students Enrolled in Two Different Bilingual Education Models

Jennifer L. H. Daves
\end{abstract}

This study compared English-reading-comprehension and oral-language-production scores of Spanish-speaking limitedEnglish proficient students in an early-exit and a late-exit transitional bilingual education (TBE) program.

For this study, 111 sixth grade students were selected from two similar school districts, one district with an earlyexit TBE program and the other district with a late-exit TBE program. The Comprehensive Test of Basic Skills (CTBS) scores of reading comprehension and Language Assessment Scales II (LAS) scores of English-oral-language production were collected and then compared for significant differences.

In this study, students enrolled in the early-exit TBE program had significantly higher oral-language-production scores than students in the late-exit TBE program. However, students enrolled in the late-exit TBE program had significantly higher reading-comprehension scores than the students in the early-exit TBE program. 


\section{DEDICATION}

To my heavenly Father who inspired me, to my earthly father who was taken before he could see me succeed, and to my husband who supported and encouraged me throughout this entire study, I dedicate this study to these three. 


\section{ACKNOWLEDGEMENTS}

I would like to acknowledge the efforts and guidance of my advisor, Dr. Alexander Sapiens and the help of Dr. Denise Murray. I would also like to acknowledge the assistance of Dr. Elba Maldonado-Colon. She went above and beyond the call of duty to assist in the completion of my study. I am thankful to both school districts' administration and secretaries for allowing me into their offices and files. I owe a great deal of gratitude to Dr. Michael Bailey, of the Naval Postgraduate School, without whose help, I could not have completed this study 
TABLE OF CONTENTS

ACKNOWLEDGEMENTS......................... v

CHAPTER

I.

Introduction....................... 1

Problem statement.................. 3

Purpose of the study................ 4

Hypotheses.................... 4

Research Questions................. 5

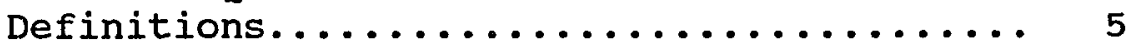

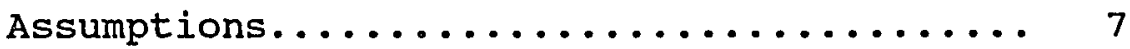

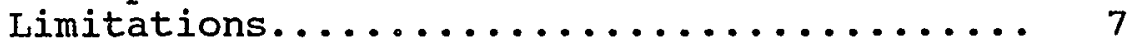

Statement of significance............ 8

II. Review of Related Literature............. 9

Introduction..................... 9

Second Language Learners Learning

English........................ 10

Effective Instructional Practices for

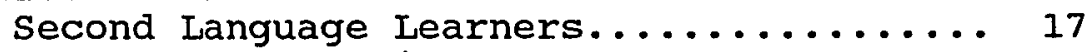

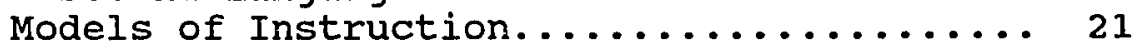

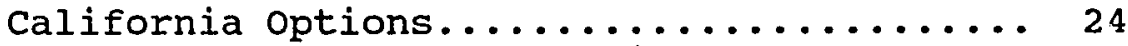

Tools to Evaluate Instructional

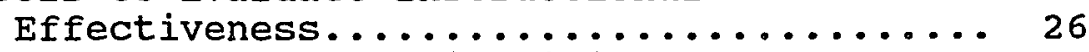

Summary of Research in Bilingual

Education.................... 30

III. $\quad$ Methodology $\ldots \ldots \ldots \ldots \ldots \ldots \ldots \ldots \ldots \ldots \ldots \ldots$

Introduction.................... 32

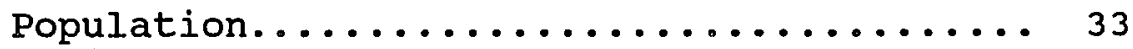

Subjects...................... 34

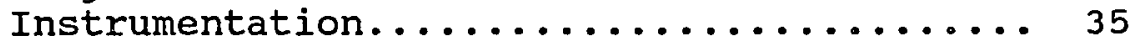

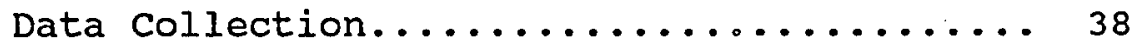

Variables........................ 38

Data Analysis.................... 39

IV. $\quad$ Findings and Discussion.............. 43

Introduction................... 43

Results............................. 44

Table 1. Comparison of CTBS and LAS II

Mean Scores for Districts $A$ and B...... 45

vi 
Table 2. Selected Comparison of CTBS Mean Scores for District A's LAS-Group and District B.................... 48

Table 3. Scatter Graph-District $A$ and District B CTBS Reading Comprehension Normal Curve Equivalence Scores........ 50

Table 4. Scatter Graph-District $A$ and District B LAS II Oral Language Production Scores................... 51

Table 5. Performance Variation I........ 52 Discussion...................... 54 Table 6. Performance Variation II....... 55

V. Conclusions and Recommendations........... 65

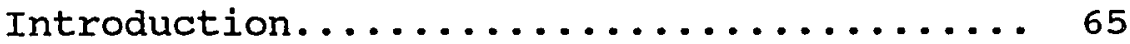

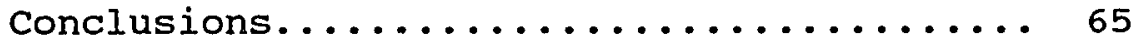

Recommendations.................. 67

REFERENCES.......................... 70 


\section{CHAPTER I}

\section{Introduction}

As of February 1992, over 80 different languages were represented in significant numbers of classrooms across California's public schools (California Department of Education [CDE] 1992a). The language minority students comprised 986,462 limited-English-proficient (LEP) students and 620,655 fluent-English-proficient students (FEP), who constitute $32.5 \%$ of the California student population. The LEP student population of 986,462 now constitutes $19.9 \%$ of the 4,950,474 students enrolled in California public schools.

The highest concentrations of LEP students are found in kindergarten through third grade. Of the california public schools' kindergarten population, $29 \%$ has been identified as LEP. The percentage gradually decreases at each higher grade level until ninth and tenth grade, where it slightly increases before dropping to $12 \%$ in eleventh and twelfth grades (CDE, 1992b).

Spanish-speaking students identified as LEP comprise the largest LEP population enrolled in California public schools (CDE, 1990). A total of $77 \%(755,359)$ of all identified LEP students speak Spanish (CDE, 1992a).

To meet staffing and instructional requirements of LEP students, the California Department of Education has devised 
six options that districts may choose from to ensure that all students, regardless of their capability in English, are afforded equal access to the general curriculum. Also, students whose proficiency in English is limited, are provided with the services they need to attain fluency in English, while following the curriculum provided to the general school population (CDE, 1991). The goal of these options is to develop each students' fluency in English as effectively and efficiently as possible, promote students' positive selfconcepts, promote cross-cultural understanding, and provide equal opportunity for academic achievement, including when necessary, academic instruction through the primary language (CDE, 1988).

Transitional Bilingual Education (TBE) programs constitute one of the options suggested by the California Department of Education. In a TBE program, the primary language is used for instructional support until students have reached satisfactory levels of English proficiency, determined by a process involving test scores and teacher observations. students are expected to move out of a TBE program when they are capable of functioning in an English-Only (EO) classroom. In many programs, the expectation is that students will be ready to make the change after a period of approximately three years (Lessow-Hurley, 1990). 
TBE programs fall into two major categories. In an early-exit TBE program the students receive a maximum of two years instruction in their first language. A late-exit TBE program often allows around $40 \%$ of classroom teaching in the first language until the 6th grade (Baker, 1993).

This study will focus on two school districts in california that have chosen to utilize TBE programs to meet the needs of their spanish-speaking LEP population. District A utilizes the early-exit TBE program, and District B utilizes the late-exit TBE program. The development of English reading and oral language production abilities in the two TBE programs in these districts was the major focus of this study.

Problem statement

An increasing number of students are entering California's public schools with spanish as a first language and limited-English production skills. As these numbers increase, there is a need to provide educational instruction that will foster academic growth, and allow spanish-speaking students to effectively acquire English as a second Ianguage. The implementation of different TBE programs, such as earlyexit, and late-exit, continues to raise questions as to which program has a greater impact in developing significant gains in English reading and oral language production scores. 
Purpose of the study

The purpose of this study was to determine the effectiveness of these two models of TBE programs in promoting English reading comprehension and oral language production abilities using the criteria most frequently used by the federal, state, and local agencies. This effectiveness was determined by specific analysis of the results of the Comprehensive Tests of Basic Skills, Form U, reading comprehension scores, and the scores on the Language Assessment Scales II, Level II.

\section{Hypotheses}

In this study, two null hypotheses were examined and tested.

1. There is no significant difference in English reading comprehension scores of sixth grade spanish-speaking LEP students in an early-exit TBE program, (District $A$ ), and similar students enrolled in a late-exit TBE program, (District B) .

2. There is no significant difference in English oral language production scores of sixth grade, Spanish-speaking, LEP students enrolled in an early-exit TBE program, (District A), and similar students enrolled in a late-exit TBE program, (District B). 
Research Questions

In this study, two research questions were examined and studied.

1. Do CTBS English reading comprehension Normal Curve Equivalent (NCE) scores of Spanish-speaking LEP students in an early-exit TBE program (District A) differ significantly from the scores of similar students in a late-exit TBE program (District $\mathrm{B}$ )?

2. DO LAS II English oral language production scores of Spanish-speaking LEP students enrolled in an early-exit TBE program (District $A$ ) differ significantly from the scores of similar students in a late-exit TBE program (District B)?

\section{Definitions}

The following terms and definitions are used in this study:

Comprehensive Test of Basic skills (CTBS): A series of norm referenced tests for kindergarten through twelfth grade. These tests are designed to measure achievement in basic skills commonly included in state and district curricula. In this study Form $U$ was used in both districts. Reading comprehension scores were utilized as the base for comparison.

Early-exit transitional bilingual education (TBE) program: An early-exit TBE program includes some initial instruction in the child's primary language of sixty to ninety 
minutes per day. This is usually limited to the introduction of initial reading skills. All other instruction is in English, with the student's primary language used only as a support for clarification (Ramirez, 1991).

Language Assessment scales II (LAS): An assessment tool designed to measure the degree to which a student displays the oral language proficiency of an average monolingual speaker. It is available in Level I for beginning students and Level II for intermediate students. Level II was used in this study.

Late-exit transitional bilingual education (TBE) program: Students in this program receive a minimum of $40 \%$ of their total instructional time in Spanish (Spanish language arts, reauing and other content areas such as mathematics, social studies, and/or science). Students remain in this program through sixth grade, regardless of reclassification as fluentEnglish-proficient (FEP) (Ramirez, 1991).

Limited-English proficient (LEP): An identifying term used to describe students who do not have developed Englishlanguage skills in the areas of comprehension, speaking, reading, and writing necessary to succeed in the school's English-only instructional program. (CDE, 1991).

Normal Curve Equivalent (NCE): An NCE score is a measure similar to a percentile but for which intervals between scores are equal. Percentiles and NCE scores are identical at the 1st, 50th and 99th percentiles. Normal curve equivalents, 
unlike percentiles may be averaged (CDE, 1991). NCE scores were used in this study because this was the score reporting format of both districts.

oral-1anguage-production: The ability of a student to speak appropriately. The main abilities are: pronunciation, extent of vocabulary, correctness of grammar, the ability to convey exact meanings in different situations, and variations in style (Baker, 1993).

Reading: A creative and constructive process having four distinctive and fundamental characteristics: it is purposeful, selective, anticipatory, and based on comprehension, all matters where the reader must clearly exercise control (Smith, 1988).

\section{Assumptions}

This study is based on the following assumptions:

The CTBS is an adequate instrument to measure Englishreading-comprehension in LEP students, since the state recommends its use based on its validation procedures.

The LAS II is an adequate instrument to measure Englishoral-language-production, since the state recommends its use based on its validation procedures.

\section{Limitations}

This study was limited to LEP sixth-grade students enrolled in District A, 54 who took the CTBS and 22 who took 
the LAS II, and a sample of LEP sixth-grade students enrolled in District B, 55 who took the CTBS and 57 who took the LAS II. This study compared the CTBS and LAS II scores of Spanish-speaking students taking English language tests. This study was based upon ex post facto scores, scores recorded in student cumulative folders.

Statement of Significance

By comparing English-reading comprehension and orallanguage-production scores of Spanish-speaking LEP students in an early-exit TBE program with those of a late-exit TBE program, the study will add to existing research on the development of second language competence. Participating districts will have a comparison for each of their programs. Teachers will have additional information as to performance in different designed programs to meet the needs of Spanishspeaking LEP students. 
CHAPTER II

Review of Related Literature

\section{Introduction}

Today there are many more bilingual individuals in the world than there are monolinguals. More children throughout the world have been and continue to be educated via a second language than the number who are educated exclusively through their first language. In many parts of the world, bilingualism and innovative approaches to education which involve the utilization of more than one language constitute the status quo, an accepted way of life, and a natural experience (Tucker, 1977).

The intellectual and educational effects of bilingualism have been the subject of considerable research for approximately three-quarters of a century (Hakuta, 1986). Initial interest in the topic was apparently stimulated by psychologists who were interested in psychometric tests of intelligence used with bilingual populations (Arsenian, 1937). Later studies were developed to confirm or disconfirm the effects of bilingualism.

Frost and Rowland (1970) and Saville and Troike (1971) point out that the mediator of educational success for the socio-economically disadvantaged child is basically communication, or more specifically, oral language. This is especially 
so in the early years of schooling when children must depend upon their ability to interact with their teachers and peers. John and Horner (1971) believe that when the non-Englishspeaking child goes to school, it is at this very age that he or she are ordinarily confronted with the demand to learn in English and to think in English.

Many existing education programs make no allowance for the fact that many spanish-speaking students enter school either (a) knowing a fair amount of English but being psychologically reluctant to use it, or (b) knowing little English, or else, (c) knowing only spanish. Thus, many Spanish-speaking students are burdened with the disadvantage of being unable to cope with English (Cummins, 1989).

This chapter is organized into five sections. First, second language learners learning English is addressed. Second, effective instructional practices for second language learners is covered. Third, models of instruction, specifically early-exit and late-exit transitional bilingual program models are outlined. Fourth, California options to instruct limited-English proficient students are addressed. Finally, tools to evaluate instructional effectiveness are discussed.

\section{Second Language Learners Learning Engl ish}

A child who is learning a second language goes through a process that has fundamental similarities to that of a child 
learning a first language (Hakuta, 1986). A baby listens to language for many years before trying to use words for communication, and when young children begin to speak, they do not use complete sentences or perfect grammar. They omit many words or parts of words, and they make errors in pronunciation, vocabulary, and grammar (Brown, 1973).

When children learn a second language, they also start with just a few words and make many errors. Both first and second language learners have to listen to the language they hear around them and try to make sense of it. They are acquiring language as they are listening, observing and participating (Wells, 1986).

In second language acquisition, many processes are involved. Three types of processes come into play, each of them intricately connected with the others. These can be described as (1) social, (2) linguistic, and (3) cognitive processes (Wong-Fillmore, 1985).

social processes include regular social contacts with people who speak the target language. This enables the learners to observe the use of the target language. Second language learners observe the speakers in dialogue, which then becomes an incentive for learning the target language (WongFillmore, 1985).

Linguistic processing in second language learners is influenced by the learners' assumption about how the target 
language works. This affects how they interpret the linguistic data to which they are exposed. This linguistic data, together with supporting social contexts in which the data are based, constitute input. Input is the material on which learners can base their acquisition of the second language (Krashen, 1981)。

The third type of process in second language learning is cognitive. The linguistic data that second language learners have as input consists of speech produced by speakers of the target language in social situations. What the second language learners must do is discover the system of rules that are being used in the second language, develop this knowledge into a grammar, and then internalize it (WongFillmore, 1985).

Second language learners apply many cognitive strategies and skills while acquiring a second language. They make use of associative skilis, memory, social knowledge and inferential skills while listening to conversation. They use whatever analytical skills they have to figure out the relationships between forms, functions and word meanings. They have to make use of memory, pattern recognition, induction, categorization, generalization, and inference, to figure out the structure of the forms of the language that can be combined, and the meanings of words adapted by changes and deletions (Wong-Fillmore, 1985). 
Children learning a second language already have a good communication system in their first language (chamot, 1981). Children may try to use parts of their first communication system in the second language. Sometimes this borrowing helps the child and sometimes it leads to errors in the second language (Savilie-Troike, 1976). Whether errors in the new language are made because children are simplifying the language, making incorrect assumptions about how it works, or transferring portions of their first language inappropriately, these error-producing processes and strategies are part of the normal second language acquisition process (Chamot, 1981; Edelsky, 1989; Franklin, 1989).

As children gain increasing skill in their first language, they tend to transfer their successful communication skills to their second language. Transfering means building on what students already know in their first language to help them learn new skilis in the second language. Transfer is a continuous process of making connections between the first and second language, while students are involved in language development activities or social contexts (Williams and snipper, 1990). For example, once he or she learns to read and write using one language, in this case Spanish, they can transfer many skills and insights to reading and writing in English. 
This process of transferring skills between languages is called the Linguistic Interdependence Hypothesis (Cummins, 1989). This principle acknowledges that the surface aspects (pronunciation, fluency, and so forth) of different languages are clearly separate. However, there is an underlying cognitive/academic proficiency which is common across languages. This common underlying proficiency makes possible the transfer of cognitive, academic, and literacy related skills across languages. Transfer is much more likely to occur from minority to majority language when students are literate in their first language (Cummins, 1989). Second language learners who have developed skills in their first language, have a foundation of skills built. This foundation provides for the transfer of these skills from their first language to the second language.

The experience of hearing and using two different languages every day is a common one for many children in the United states, and throughout the world (Tucker, 1977). A number of studies have been conducted concerning bilingual children. Findings suggest that while children may experience some initial confusion when acquiring two language systems at once, this disappears as soon as children mature and become more proficient in both of their languages (McLaughlin, 1983). Bilingual children will also switch from one language to the other, even in the middle of a sentence. This is a normal 
habit for bilinguals of any age when conversing with other bilinguals (Saville-Troike, 1976). Some studies show that bilingual students not only have linguistic advantages over their monolingual counterparts, but they may be superior in cognitive processing activities (Lambert, 1981).

Most children find it easier to keep two languages separate when each is used for certain situations and people. In fact, most bilinguals prefer one language over the other in certain situations (Chamot, 1981).

Recent research suggests that varied different time periods are required for minority students to achieve peerappropriate levels in conversational skills in the second language as compared to academic skills in the second language. Conversational skills often approach native-like levels within about two years of exposure to English, whereas a period of five years or more may be required for minority students to achieve as well as native speakers in academic aspects of language proficiency (Collier, 1987; Collier and Thomas, 1988; Cummins, 1981, 1984; Wong-Fillmore, 1983). The relatively long period of time required for language-minority students to attain grade norms in academic aspects of English can be attributed to the fact that native English speakers continue tc make significant progress in English academic skills year after year. They do not wait for the minority student to catch up. 
In conversational skills, after the first six years of life, changes tend to be more subtle. In conversation, the meaning is supported by contextual cues, whereas this is seldom the case for academic uses of language. Typical everyday conversational interactions can be characterized as context-embedded and cognitively-undemanding while academic tasks tend to become increasingly context-reduced and cognitively-demanding as students advance through the rrades (Cummins, 1989). For example, a context embedded and cognitively-undemanding interaction is when the second language learner is familiar with the context of the situation, and the conversation requires undemanding thought. A context-reduced and cognitively-demanding interaction is when the second language learner is not familiar with the context of the situation, and the conversation requires demanding thought.

The research evidence suggests that although there are large individual differences between children in the rapidity with which they acquire different aspects of English proficiency (Wong-Fillmore, 1983), psychological functioning verbal tests or verbal achievement tests tend to underestimate minority students' academic potential until they have been learning a second language for at least 4-5 years. 


\section{Effective Instructional Practices for Second}

\section{Lanquage Learners}

The single most important contribution that literacy research has made to teaching over the last dozen years, is that second language learning must take place in a meaningful context (Williams and Snipper, 1990). The use of phonics and sight vocabulary are two approaches that fail to take context into account. In most bilingual classes, the curriculum focuses on functional literacy skills, such as phonics and sight vocabulary, rarely expanding to include the social and critical facets of literacy that are so important to academic achievement (Edelsky, Altwerger and Flores, 1991).

Researchers have identified a number of significant bilingual instructional features that appeared in identified successful bilingual classrooms. These features included: (1) active teaching behaviors, (2) cultural referents from the LEP students' home culture that were actively used during instruction, (3) two languages used to mediate instruction, and (4) English language development integrated with regular class instruction (Tikunoff, 1983). The active involvement of students in the learning process, characterizes effective teaching in any type of bilingual or regular classroom (Milk, 1990).

Wong-Fillmore (1982) found that the best language learning situations were those where children were grouped by 
language ability for instruction and where both languages were used as mediums of instruction. Opportunities for informal language development from their English-speaking peers also benefited LEP students. Another significant finding of the best second language learning situation was when the teacher was actively involved in the learning situation, directed instruction when students were working in small groups, and monitored student's responses in large as well as small group work. overall, the teacher was very involved with active instruction and allowed students plenty of opportunities for language development to occur (Garcia, 1990).

An effective instructional practice that has produced achievement gains for minority students is the use of cooperative learning strategies. Cooperative learning refers to the structuring of classrooms so that students work together in small cooperative groups. The achievement gains observed in cooperative classrooms are particularly dramatic for minority students. Non-minority and high-achieving students generally perform about as well in traditional and cooperative classrooms, and low-achieving and minority students appear to be more motivated to learn in classrooms with cooperative groups. Kagan (1986) concluded that minority students may lack motivation to learn when they are placed in traditional, competitive, and individualistic classroom structures. What seems to appear as a long-term 
minority-student deficiency in basic language skills, can be overcome by transforming the social organization of the classroom. The gap in achievement between majority and minority students is not attributed to the personal deficiencies of minority students, but rather to the exclusive reliance in public schools on competitive and individualistic classroom arrangements (Cummins, 1989).

According to Saville-Troike (1983), instruction for second language learners should include greater reliance on content-based instruction as a more effective way to develop the full academic potential of LEP students. One approach utilized for second language instruction that utilizes content-based instruction is the Language Experience Approach (LEA) (Rigg, 1989). LEA is based on the observation that children remember best what is most meaningful to them and what they themselves have generated. It focuses on developing reading materials from invented stories or narrative accounts of events that students write and/or dictate (Williams and Snipper, 1990).

Another approach used is the Core Literature approach. This approach implies that a significant purpose of reading is to enjoy good literature. It actively endorses teaching phonetic skills and sight vocabulary as comprehension tools within the context of the story. The reading related activities teachers provide for students are crucial in making 
the Core Literature approach context-centered and meaningful (Williams and Snipper, 1990).

The use of reading and writing scaffolds for second language learners is an approach used for teaching literacy skills. Scaffold use in second language acquisition assists with the construction of meaning. Teachers, manage this strategy by assisting the student in elaborating language and building effective communication. The scaffold allows the student to have enough assisted practice in a particular structure or technique for acquisition to take place. Once the structure or technique is acquired, the scaffold is no longer necessary and students then have a literacy base from which to write or read in the second language (Peregoy and Boyle, 1990). The use of scaffolding focuses on using meaningful, whole texts with repeated language patterns as the basis of reading and writing activities. This modeling of reading and writing processes by the teacher or peers help second language students comprehend and produce at a level slightly beyond their usual level of performance (Peregoy and Boyle, 1990).

Lucas, Henze, and Donato (1990) conducted a case study in six schools in California and Arizona. This research revealed eight features that are important in promoting success of language minority students. These findings included: value and status given to the minority-students' language and 
culture, (2) high expectations of language-minority students, (3) school leaders giving the education of language-minority students a high priority, (4) staff development designed to help all the staff effectively serve language-minority students, (5) a variety of courses for language-minority students were offered, (6) a counseling program was available, (7) parents of language-minority children were encouraged to become involved in their children's education, and (8) school staff were committed to the empowerment of language-minority students through education.

\section{Models of Instruction}

During the last decade, research has clearly demonstrated that certain effective schools successfully educate students who are at a disadvantage. Research on effective schools challenges the basic assumption that family social variables predetermine student outcomes (Carter and Chatfield, 1986). It is certain that in some schools, poor and disadvantaged minority students behave academically in ways similar to their more socio-economically advantaged majority-group peers (Rutter, 1983). Research on effective schools supports what every thoughtful educator knows intuitively, schools can make a very real difference when meaningful curriculum and instructional strategies are implemented (Carter and chatfield, 1986). As the number of limited-English proficient (LEP) 
students in California increase, this has led researchers to focus on the identification of instructional programs that are effective and meet the special learning needs of LEP students.

Several instructional programs have been developed over the years to attempt to meet the needs of language-minority students. These programs are identified as: (1) English-only (EO) instruction, (2) English as a second language (ESL), instruction, (3) transitional bilingual education (TBE) programs, and (4) structured English immersion strategy (SEIS) programs (Ramirez and Merino, 1990). The type of program focused upon in this study j.s transitional bilingual education (TBE). Therefore, this section will deal specifically with the description of this type of program. In TBE programs, language-minority students study subject matter in their primary language until they have learned enough English to succeed in English-only (EO) mainstream classrooms. Children in TBE programs learn to read in their first language and then in English. ESL is a key component of the TBE programs (Ramirez and Merino, 1990).

Transitional bilingual education programs fall into one of two instructional models, early-exit and late-exit. They are similar in many ways, however they differ substantially in the role of $L I$ and the length of instruction in LI (Ramirez and Merino, 1990). 
In an early-exit TBE program, II is developed and used for content area instruction. Generally, Ll is used for approximately one hour per day in kindergarten and its' use quickly tapers off in grades one and two. LI is used not so much to teach the content areas as it is used to clarify and support instruction in English. Students are mainstreamed into EO programs as soon as they demonstrate oral proficiency in English, usually occurring within two or three years after entry into the program. Thus a LEP student entering kindergarten would be mainstreamed at the end of first or second grade (Ramirez and Merino, 1990).

A late-exit TBE program, focuses its efforts on the development of $\mathrm{LI}$ to enhance learning opportunities and the acquisition of advanced language and cognitive skills. Thus, efforts are taken to develop LI proficiency and $\mathrm{LI}$ is used extensively for content area instruction. Approximately $50 \%$ of total instruction is conducted in Ll. In this type of program a student is not mainstreamed into an EO program until after fifth or sixth grade, regardless of when oral proficiency in English is demonstrated (Ramirez and Merino, 1990)

Federal policy favors transitional bilingual education programs. They are the most common models in use today. However, TBE programs are characterized by a number of inherent problems. These problems include: (a) subtractive 
rather than additive bilingualism is fostered. (b) a compensatory type program that does not involve the monolingual English-speaking community is used, (c) exit assessments which measure students' conversational language skills but fail to consider the specialized language skills needed for academic success are utilized, and (d) unrealistic expectations about how long it takes children to master a second language are found. (Lessow-Hurley, 1990). Ramirez, Yuen, and Ramey (1991) verified that the most effective type of instruction program for second language learners is one which offers the opportunity for dual language development, while enhancing the learning opportunity and the acquisition of advanced language and cognitive skills.

\section{California options}

To meet the staffing and instructional requirements of LEP students, the California state Department of Education has devised six options that districts may chose from, in order to ensure that all students, regardless of their capability in English are afforded equal access to the regular curriculum. Also, students whose proficiency in English is limited will be provided with the services they need to attain fluency in English, while at the same time following the curriculum provided to the general school population. According to the 
California Department of Education (1991) these options include:

Option \#I Districts may demonstrate compliance with requirements to serve LEP students by submitting test results that demonstrate that LEP or former LEP students are performing on a level equal to or above that of all students statewide or that current LEP students are learning at a sufficiently rapid pace to close the gap between their performance and that of all students. Districts may use objective tests such as the California Assessment Program (CAP) test or norm-referenced tests to compare the performance of their LEP or former LEP students with that of national or statewide averages.

Option \#2 Districts shall be considered in compliance by assigning teachers who hold Commission on Teacher Credentialing (CTC)-issued teaching authorizations to instructional positions in the areas of English Language and/or primary language development.

Option \#3 Districts may comply with the requirements by designating other qualified teachers to serve such students, according to students' needs.

Option \#4 Districts may comply with requirements by submitting plans to remedy the shortage of qualified teachers by 1) hiring teachers already qualified to teach in the district's LEP programs, or 2) providing in-service training to the district's current teachers. Districts must submit long-range plans to remedy the shortage of qualified teachers.

Option \#5 Districts shall be considered in compliance by obtaining a general waiver from the state Board of Education from any requirement of the state's program for LEP students, with the exception of LEP pupil identification and language census procedures. 
Option \#6 This option is an exemption from the requirement to adopt and implement one or more of the program options. This option applies to districts with fewer than 51 LEP students of a single language group, and fewer than 21 LEP students from the same language group at any school. The option allows districts to design special instructional services and staff training programs in concert with the Department's Bilingual Education Office. (p. 3)

The goal of these options is to develop fluency in English in each student as effectively and efficiently as possible, promote students' positive self-concepts, promote cross-cultural understanding, and provide equal opportunity for academic achievement, and when necessary, providing academic instruction through the primary language (CDE, 1988).

\section{Tools to Evaluate Instructional Effectiveness}

The focus of this study was on reading comprehension and oral language production scores as measures of instructional effectiveness. The two tests used as measures were the Comprehensive Test of Basic skills (CTBS) and the Language Assessment Scales II (LAS). Each of these tests has been used for many years to assess the progress of LEP students.

In this study CTBS scores of reading comprehension were used. According to CTB/MCGraw-Hill (1984), the reading comprehension section of the test measures the following objectives: 
(a) The student will extract details from a passage to answer who, what, where, or when questions, (b) The student will analyze the feelings, traits, or motives of characters in a passage, (c) The student will identify the main idea, the author's purpose or view point, or the tone and mood expressed in a passage, (d) The student will draw conclusions from or recognize cause and effect relationships in a passage, (e) The student will differentiate between reality and fantasy, between fact and opinion, or between forms of writing, and (f) The student will recognize techniques of persuasive writing or figurative writing (p. 265).

on scoring reports, the criterion-referenced performance indicators for objectives are listed for both individuals and groups. Performance was being identified as mastery, partial knowledge, or nonmastery. It is believed that the CTBS objective mastery indicators are useful as reference points in the educational process, but no claim of infallibility is made regarding them. Educators and evaluation specialists do not agree on what mastery is or how best to measure it. The objective-mastery indicators are not intended to be standards, but guidelines (CTB/MCGraw-Hill, 1984).

The position of CTB/MCGraw-Hill concerning test bias is based on some general propositions. First, students come to school with differences in background knowledge, skills, language, attitudes and values. second, it is the school's job to increase knowledge that is common to all, and to develop certain basic cognitive skills in all students. Third, for some groups, family languages and cultures are different from the majority group. Therefore, no test that is 
designed to be used nationally can be completely unbiased. The best that can be done is to minimize extraneous elements of the test, there-fore increasing the number of students for whom the test will be appropriate (CTB/MCGraw-Hill, 1984). The Language Assessment Scales II (IAS) were used to measure oral language production of students participating in this study. The LAS measures the degree to which a student displays the oral language proficiency of a competent monolingual speaker. There are both English and Spanish versions of the test. In this study, only the English version was used. The LAS contains seven subtests, the last two subtests are optional. The five sub-tests assess oral language proficiency by minimal pairs, phonemes, lexicon, syntax, and oral production. Written production and pragmatics can be assessed for children grades seven and above. A score derived from an observation of the student to be conducted by an adult other than the examiner is also optional. The LAS is administered individually. The five sub-tests which are given to every student require at least 20-30 minutes. Of these five sub-tests, all but lexical items are tested using the LAS cassette tapes (Mitchell, 1985). If the LAS is used only to decide whether a child has the proficiency of a monolingual first grader, or seventh grader, then this is a powerful test, though it has some serious practical difficulties of administration and scoring. If the 
test is to be used for a more fine-grained analysis of language proficiency or to predict future school achievement, then the test is inadequate, not only for these practical reasons, but because of serious theoretical and methodological difficulties in test construction. The LAS authors stress that reliable results can only be obtained if testing is performed in quiet and nondistracting settings. Few school personnel have the proper qualifications to administer the LAS. The tester must speak the test language fluently as a first language. Reliable scoring of the test requires either in-service training or extensive work with someone already trained (Mitchell, 1985).

The IAS in its present form presents almost overwhelming practical problems if used to identify children for bilingual classrooms. Serious methodological and theoretical difficulties in test construction prevent the use of the LAS to specify a quantitative description of a child's present language proficiency, much less to predict future school achievement or to serve as a basis for intervention. However, as a measure of oxal language proficiency the LAS has two outstanding virtues. First, that it includes measures of phonological, lexical, and syntactic knowledge. The second virtue is that the LAS relies heavily on the student's spontaneous, controlled utterances that allow for evaluation 
of productive skills as well as receptive skills (Mitchell, 1985).

Summary of Research in Bilingual Education

Recent articles by Carter and Chatfield (1986), Lucas, Henze and Donato (1990), Baker (1990), and CZiko (1992) have suggested that the effectiveness of bilingual education can be addressed from a perspective other than standard test measures. Bilingual education research can look at program effectiveness at four different levels, the first level being the effectiveness of bilingual education at the individual child's level. Within the same classroom, some children respond and perform differently to the program. The second level to examine is the effectiveness of bilingual education at the classroom level. In the same school and type of bilingual education program, bilingual classrooms can be very different. It is also important to analyze the factors connected with varying effectiveness at the classroom level. The third level of effectiveness analyzed is at the school level. Some schools are more effective than others, even with the same type of bilingual education program and similar students. The fourth level of effectiveness to look at it beyond the school level. There are groups of schools and districts that have different types of bilingual education programs which are effective. 
The effectiveness of bilingual education must take into account the social, political, and cultural context in which education is placed. It is important in bilingual education effectiveness research to examine a wide variety of outcomes from education other than the standard measures. Such variety may include examination results, tests of basic skills, and the broadest range of curriculum areas. Non-cognitive outcomes are also important and should be included in an assessment of effectiveness. Such non-cognitive outcomes may include: attendance at school, attitudes, self-concept and self esteem, social and emotional adjustment, and moral development (Baker, 1993).

The point beind such a comprehensive consideration of bilingual education is that effective bilingual education programs are not a simple or automatic consequence of using a child's first or second language in school. Many home and parental, community, teacher, school and societal effects may act and interact to make bilingual education more or less effective. The importance of different ingredients and processes in various school and cultural contexts needs to be investigated to build a comprehensive and wide ranging theory of when, where, how and why bilingual education programs can be effective (Baker, 1993). 
CHAPTER III

Methodology

\section{Introduction}

An increasing number of students entering California's public schools are of limited-English proficiency. They have Spanish as their first language. As these numbers increase, the need to provide instruction that fosters academic growth and promotes acquisition of English as a second language, becomes crucial to their education process.

This study sought to determine whether spanish-speaking LEP students in an early-exit transitional bilingual education (TBE) program attained significantly different scores in English reading comprehension and/or English oral language production than those of similar students in a late-exit TBE program. Scores of results obtained through two independent measures were compared across districts. Statistical significance was determined at the $\mathrm{p}<0.05$ level.

Two hypothesis were developed to test:

(1) There is no significant difference in English reading comprehension scores of Spanish-speaking LEP students in an early-exit TBE program and similar students in a lateexit TBE program.

(2) There is no significant difference in English oral language production scores of Spanish-speaking LEP students in 
an early-exit TBE program and similar students in a late-exit TBE program.

\section{Population}

The school districts participating in this study will remain anonymous. To protect this anonymity, letters are assigned to name each district. The district representing the early-exit TBE program is identified as District $A$. The district representing the late-exit TBE program is identified as District $B$.

students in District $A$ are in an early-exit TBE program from kindergarten through third grade. In this program, some initial instruction is in the student's primary language, usually 60 to 90 minutes daily. This time is used for the introduction of initial reading skills. All other instruction is in English, with the student's primary language used only as a support for clarification. students in this TBE program are expected to be exited from the program and mainstreamed into an English-only program by the end of first or second grade.

Students in District B are in a late-exit TBE program from kindergarten through fifth grade. These students receive a minimum of forty percent of their total instructional time in spanish (Spanish language arts, reading, math, social 
studies and/or science). Students remain in this program through the fifth grade.

District $A$ has 1,741 students enrolled in grades $K-8$, with 53.7 percent identified as Spanish-speaking, LEP students (CDE, 1990). District $B$ has 4,796 students enrolled in grades K-6, with 53.5 percent identified as Spanish-speaking, LEP students (CDE, 1990). The Bilingual Education office of California Department of Education ranks school districts in order of percentage of LEP students. District A was ranked as number 18 in the state, by the percentage of students within the district enrolled as LEP. District $B$ is ranked number 19 in the state by the percentage of the students within the district enrolled as LEP (CDE, 1990). These findings indicate similarities of the student populations being compared. The students enrolled in both districts were from working class families classified in the lower socioeconomic range from the skilled/semi-skilled and unskilled categories.

\section{Subjects}

The three criteria for selecting students for this study were: (1) Spanish was identified as their first language, (2) students were identified in each district as LEP; and (3) each student was enrolled in their representative school district for seven consecutive years. The study was limited to sixth 
grade students because current research indicates that second language acquisition occurs within 5-7 years of second language instruction/acquisition (Cummins, 1989). Due to the high mobility of the student families, only a small number of students met these criteria. Therefore, all students who met these criteria were used in this study.

In the spring of 1992, the scores of all qualifying students in District $A$ and District $B$ were collected for analysis. The distribution of male scores and female scores was nearly equal (Table 1). The scores selected reflect available data, not necessarily numbers of students. In District $B$, only two students did not have matched tests. That is, of the 112 scores reported, 110 scores represent 55 students having taken the CTBS and the LAS II. Whereas in District A, only 32 of the 76 scores reported represent 16 students having taken both tests.

\section{Instrumentation}

Two measures recommended by the California Department of Education were used as the tools for data collection. students are administered both of these measures yearly until they exit the bilingual program. Thereafter, only the CTBS continues to be administered. The Comprehensive Tests of Basic skills (CTBS) is a series of norm-referenced tests used to measure reading from kindergarten through the twelfth 
grade. It is published by CTB/MCGraw-Hill of Monterey, California. The series is designed to measure achievement in the basic skills commonly found in state and district curricula. The curricular area of the CTBS utilized in this study was reading (reading comprehension). The level and grade range applicable to this study was Form U, Level G, 4.66.9. The test was taken by students in both districts in the spring of 1992. The CTBS test was used for this study's score comparisons, because it was utilized by both districts.

Testing for standardization of the CTBS was conducted by CTB/MCGraw-Hill in the Fall of 1980 and spring 1981. The tests were administered to a large national sample in grades K-12. The public school sample was stratified by geographic region, community type (urban, suburban, rural), district size (average elementary grade enrollment), and a demographic index based on community characteristies related to district achievement (CTB/McGraw Hill, 1984). However, the sample used in standardization of the CTBS does not represent the students in this study.

The LAS II is a convergent-assessment measure. The LAS II provides an overall picture of oral language proficiency based on a student's performance across four linguistic subsystems. These subsystems include the phonemic system, the referential system, the syntactic system, and the pragmatic system. The goal of the LAS II is to assess the student's 
oral language abilities in these four subsystems of English and/or Spanish. The results provide a general understanding of the level of linguistic proficiency based on the total composite score of the four subsystems. The LAS II test was used for this study's score comparisons, because it was utilized by both districts.

Validity of the LAS II was established by the Iinguametrics Group testing English-speaking and Spanish-speaking children. One hundred seventy children were informally identified for linguistic competency in both English and Spanish by teachers and other school personnei familiar with the familial and socio-cultural background of each child. In a series of one-way analyses of variances (ANOVA), the performance of children identified as high English/low Spanish was compared with the performance of children identified as low English/high Spanish across each sub-test of both English and Spanish versions of the LAS II. Significant differences were found between groups for every sub-test as well as for the total test. The total test score reveals English dominant speakers scoring a mean score of 86.78 on the English test. The Spanish test score for English dominant speakers was 70.24. The total test score for spanish dominant speakers on the English test was 75.21 and for the Spanish test the mean score was 85.53 (Duncan and DeAvila, 1978). 


\section{Data Collection}

Written permission to obtain access to student information was obtained from each participating district. Parental permission was not needed because student anonymity was guaranteed by assigning numbers to represent each student. The students were selectea from each district's list of LEP students. Cumulative folders were checked to verify seven consecutive years of enrollment in the school district and to obtain test scores from the 1991-92 school year. Tables were used to record student test score data next to assigned student numbers.

Two separate test scores were collected, one score for English reading comprehension and the other for oral language production. The CTBS Form U, Level $G$ was used to assess English reading comprehension of the subjects. The reading comprehension scores are reported in the form of Normal Curve Equivalence (NCE). This was because the $\bar{N} C E$ score was the only reported score that both district's had that was comparable. The LAS II was used to assess oral language production. The scores were reported in the form of a level score, which was derived from converting the total test score.

\section{Variables}

Scores on school measures of academic achievement are considered dependent variables since they should be influenced 
in some way by the type of educational program. The academic or dependent variables were (a) the standardized test score of the CTBS in reading comprehension, and (b) the oral language production score of the LAS II.

In this study, the form of education was the independent variable. The form of the TBE program is seen as a factor effecting performance. Effects are assumed to be dependent upon differences in the independent variable.

The collected and compared scores in this study were only those of students who were identified as LEP upon enrollment in kindergarten in each district, spanish was identified as their first language, and they were enrolled in each district, seven consecutive years.

\section{Data Analysis}

The purpose of the data analysis is to describe the data statistically to confirm or dispute the hypotheses. In this study, data is represented in the following form:

CTBS $_{A}=$ expected CTBS scores for District $A$

$I_{A} S_{A}=$ expected LAS scores for District $A$

CTBS $_{B}=$ expected CTBS score for District $B$

LAS $_{B}=$ expected LAS scores for District $B$ 
CTBS $_{A}$ is a population parameter estimated by $C_{A}$, the average of the observed CTBS scores in District $A . \mathrm{CTBS}_{B}$ is a population parameter estimated by $C_{B}$, average of the observed CTBS scores in District B.

LAS $_{A}$ is a population parameter estimated by $L_{A}$, the average of the observed LAS scores in District $A$. LAS $B$, is a population parameter estimated by $\mathrm{I}_{B}$, average of the observed LAS scores in District B.

The hypotheses are then:

1. $\mathrm{H}_{\mathrm{o}}: \operatorname{CTBS}_{\mathrm{A}}=\mathrm{CTBS}_{\mathrm{B}}$

2. $\mathrm{H}_{0}: \operatorname{LAS}_{\mathrm{A}}=\operatorname{LAS}_{\mathrm{B}}$

The first null hypothesis was: 1. There is no significant difference in English reading comprehension scores of Spanish-speaking LEP students in an early-exit TBE program and those of similar students in a late-exit TBE program. The second null hypothesis was: 2. There is no significant difference in English oral language production scores of Spanish-speaking LEP students in an early-exit TBE program and those of similar students in a late-exit TBE program.

It was determined that in case of unequal subject size a choice would be made between two $t$-tests to examine the hypothesis. A Type I t-Test was used when the variances were equal. A Type II t-Test was used when the variances were unequal. The choice of t-tests was dictated by the equality 
of the variances of the two populations. Data in this type of analysis is represented as follows:

$\sigma_{A}^{2}$ (CTBS) = variance of District $A^{\prime} s$ CTBS scores

$s_{A}^{2}$ (CTBS) = sample variance (estimate of $\sigma_{A}^{2}$ (CTBS))

The choice of which $t$-Test to use for the CTBS hypothesis was based on whether or not $\sigma_{A}{ }^{2}$ (CTBS) $=\sigma_{B}^{2}$ (CTBS). Hence, it was necessary to test:

$$
\mathrm{H}_{0}: \quad \sigma_{A}^{2}(\mathrm{CTBS})=\sigma_{B}^{2} \text { (CTBS) }
$$

The choice of which t-test to use for the LAS hypothesis was based on whether or not $\sigma_{A}{ }^{2}$ (IAAS) $=\sigma_{B}^{2}$ (LAS). Hence, it was necessary to test:

$$
\mathrm{H}_{0}: \sigma_{A}^{2}(\text { LAS })=\sigma_{B}^{2}(\text { LAS })
$$

All of the test statistics and test forms used were found in Hogg and Tannis (1977).

To verify the above hypothesis, an analysis of variance was conducted.

If a tested statistical value which is implausible was observed (with significance $\mathrm{p}<0.05$ ) it would imply that the variances of the two populations are different.

The analysis proceeded as follows for each of the original hypotheses.

I. Determine whether the variances of the two populations were equal. 
II. If they were equal, perform a Type I t-test, if they were different, perform a Type II t-test. After determining if variances were equal, then the $t-$ tests were performed. In this study both Type I and Type II t-tests were used. 
CHAPTER IV

Findings and Discussion

\section{Introduction}

The purpose of this study was to determine if there were significant differences in the scores of Spanish-speaking LEP students in an early-exit TBE program compared to those of students participating in a late-exit TBE program. The scores analyzed were English reading comprehension and English oral language production.

In this study, the type of educational program is the independent variable. The two values of this variable are an early-exit TBE program, and a late-exit TBE program. The dependent variables are scores of a measure of English reading comprehension and scores of a measure of English oral language production.

The results of this study are presented on the following pages in Tables 1 through 6. All scores used for English reading comprehension were those on the CTBS, Form U, administered to the students during the spring of 1992. AlI scores for English oral language production were those from the LAS II, administered to the students during the 1991-92 school year. 
Results

Findings of this study suggest that student participation in a late-exit TBE program results in higher performance in reading comprehension, while participation in an early-exit TBE program does not show equal or higher performance. However, students in the early-exit program did show higher levels of English oral language development. Two hypotheses tested support these findings.

In case of the first null hypothesis, which compared CTBS reading comprehension scores, the variances were found to be unequal. Therefore, a Type II t-test was performed. Since $\underline{\underline{z}}$ $>1.96$, the original null hypothesis can be rejected at the $p$ $<0.05$ level of significance. In other words, the CTBS scores were significantly different.

In case of the second null hypothesis, which compared IAS II scores, the variances were found to be equal. Therefore, a Type I t-test was performed. $\underline{z}$ is a standard normal random variable. The original hypothesis can be rejected at the $\mathrm{p}<$ 0.05 level of significance. Thus, it was concluded that the LAS II scores were significantly different.

Comparison of CTBS and LAS II Mean scores for District's A and B. Mean score comparisons between the two districts for reading comprehension (CTBS) and oral language production (LAS II) appear on Table 1. Column A enumerates the number of 
Table 1

Comparison of CTBS and LAS II Mean Scores for Districts A and $B$

District

Test

CTBS

Reading

Compre-

hension

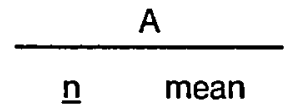

$\frac{\text { B }}{\underline{\text { mean }}}$

$\frac{\text { Difference }}{\underline{\mathrm{n}}}$

Boys

Girls

District

$\longrightarrow$

$\underline{n}$

$\begin{array}{ll}29 & 29.1\end{array}$

$28 \quad 38.1$

$-9.0$

$25 \quad 36.3$

$27 \quad 35.4$

$+0.9$

$\begin{array}{ll}54 & 32.7\end{array}$

$\begin{array}{ll}55 & 36.8\end{array}$

$-4.1$

LAS II

Oral

Language

Production

Boys
Girls
District

$11 \quad 4.3$

$28 \quad 3.9$

$+0.4$

$11 \quad 4.0$

$29 \quad 3.5$

$+0.5$

District

$22 \quad 4.2$

$\begin{array}{ll}57 & 3.7\end{array}$

$+0.5$

Note. District $A$ is the early-exit school district and District $B$ is the late-exit school district. 
boys, and girls from District $A$ who had reading comprehension and/or oral language performance scores available. The number for each of the two components also appear on this column. The number of CTBS $(n=54)$ is larger than the LAS II number $(n=22)$ because for 32 students the LAS II scores on record were older than 1991-1992, the year this study uses for analysis purposes. Thus, the older data could not be used for comparison.

For District A the boys' mean reading comprehension score was 29.1, the girls' mean reading comprehension score was 36.3, for a district mean score of 32.7. The boys' mean oral language production score was 4.3 , the girls' mean score was 4.0, for a district mean of 4.2 .

column $B$ includes the scores of boys and girls from District $B$ who took the reading comprehension and/or the oral language measure. The number for each of the two components is fairly similar (CTBS $n=55$ and LASII $n=57$ ). The boys' mean 38.1 , the girls' mean reading comprehension score was 35.4 , for a district mean score of 36.8. The boys' mean oral language production score was 3.9 , the girls' mean score was 3.5, for a district mean score of 3.7 .

The third column represents the difference between Districts' A and B scores for CTBS and LAS II. The difference between the boys' mean reading comprehension score from District $A$ and District $B$ was -9.0 . The difference of the 
girls' mean reading comprehension score from District $A$ and District $\mathrm{B}$ was +.09 . Overall, the mean reading comprehension score from District $A$ and District $B$ reflect a difference of -4.1. The difference between the boys' mean oral language production scores from District $A$ and District $B$ was t0.4. The difference of the girls' mean oral language production scores from District $A$ and the girls' mean score from District B was +.05. Overall, the difference of mean oral language production scores between District $A$ and District $B$ was +.05 .

Verification of numerical differences. Table 1 column A revealed a discrepancy in the number of scores reported for the CTBS and the LAS II in District $A$. This merited further study to find out if there would be no difference when District A'S LAS II score group had their mean reading comprehension score compared with District $B^{\prime} s$ mean reading comprehension score.

An additional Type II t-test was performed including onlyy students with matched tests. That is, only the scores of those students from District A who took the CTBS and the LAS II were compared to those of District B. Results of this test are shown in Table 1. Analysis of mean CTBS score comparisons of the LAS-Group from District $A$ and District $B$ appear in Table 2. Column A contains the total student scores from District $A$ participating in this reading comprehension section 
Table 2

Selected Comparison of CTBS Mean Scores for District A's LASGroup and District B
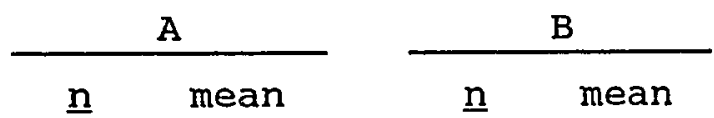

Difference

n mean

$\underline{n}$

CTBS

Reading Compre-

\begin{tabular}{lllll}
\hline 16 & 26.1 & 55 & 36.8 & -10.7 \\
\hline
\end{tabular}
hension

Note. District $A$ is the early-exit school district and District $B$ is the late-exit school district. 
of this study. The district mean score was 26.1. Column B contains the total of students' scores from District $B$ participating in this reading comprehension section of this study. The mean score of 36.8. The column labeled as difference contains the difference of the districts' mean reading comprehension scores. The difference of the scores was -10.7. The reason District A's IdAS-Group had only 16 scores was because of the 22 original studenis with LAS scores, only 16 of the 22 had CTBS scores.

Reading Comprehension scores. Table 3 compares District $A$ and District $B$ reading comprehension Normal Equivalence Scores in the form of a scatter graph. This graph reveals that both districts' reading comprehension scores are below the 50th percentile. It also reveals the scores in District $B$ to be clustered between the 30 th and 45 th percentile, while the scores from District $A$ reveal no clustering but a broad spread among the scores.

oral-Language production scores. Table 4 compares District $A$ and District $B$ LAS II oral language production scores in the form of a scatter graph. This graph reveals both districts' scores clustering around the score of 4.00 . 
Table 3

Scatter Graph - District A and District B CTBS Reading

\section{Comprehension Normal Curve Equivalence Scores}

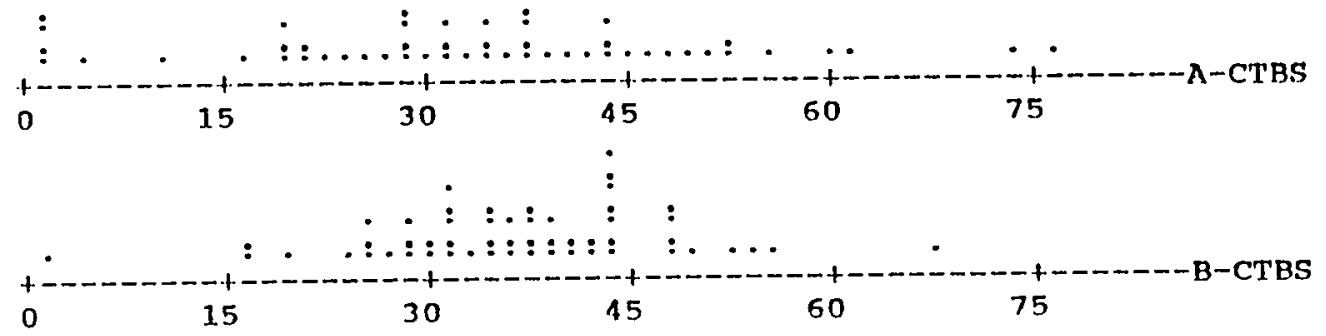




\section{Table 4}

Scatter Graph - District A and District B I.AS II Oral Language Production Scores
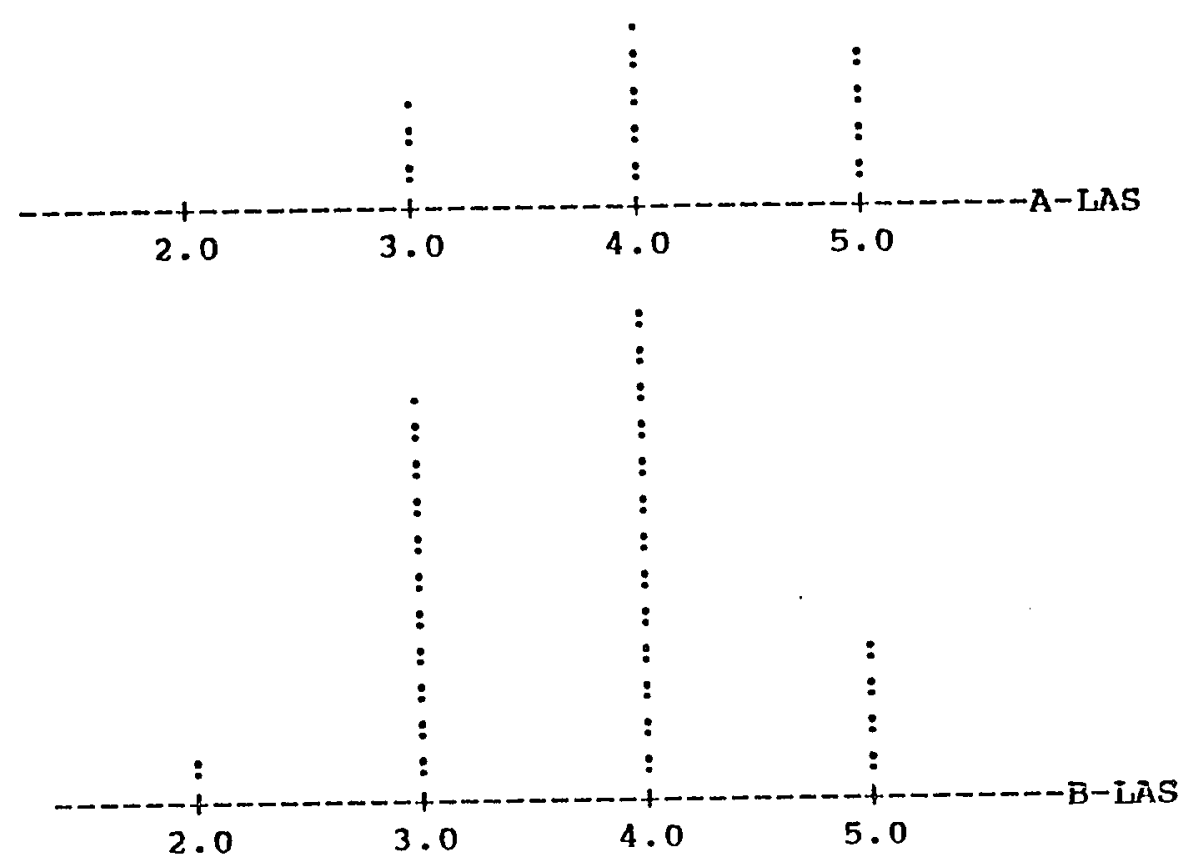
Table 5

Performance Variation I

\begin{tabular}{lcccl}
\hline $\begin{array}{c}\text { Test } \\
\text { Used }\end{array}$ & $\begin{array}{c}\text { Variances } \\
\text { Same? }\end{array}$ & $\begin{array}{c}\text { II. } \\
\text { t-Test } \\
\text { Used }\end{array}$ & $\begin{array}{c}\text { III. } \\
\text { Accept } \\
\text { or } \\
\text { Reject }\end{array}$ & Conclusion \\
\hline CTBS & No & II & $\begin{array}{l}\underline{z}=-5.0 \\
\text { Reject }\end{array}$ & $\begin{array}{l}\text { District B } \\
\text { Significantly } \\
\text { Higher }\end{array}$ \\
\hline LAS II & Yes & I & $\underline{\underline{z}}=2.25$ & $\begin{array}{l}\text { District A } \\
\text { Significantly } \\
\text { Righer }\end{array}$ \\
\hline
\end{tabular}


Performance variation I. Comparisons of the two districts' mean scores for reading comprehension (CTBS) and oral language production (LAS II), using the formulas stated in chapter Three, appear on Table 5. Column I contains the result of the test for equal variance of CTBS performance. After CTBS scores reported for both districts were tested to determine equal variance, it was found that the variances were not the same, indicating it was necessary to use the Type II t-Test. Column II indicates the use of the Type II t-Test. Column III reveals that the Type II t-Test confirmed a difference between the scores, with $\underline{\underline{z}}=-5.0$ being outside the $(-1.96,1.96)$ acceptance region. Therefore, the first hypothesis was rejected. Column IV shows that District B had a significantly higher mean CTBS score than District A.

Table 5 also includes results of the analysis of the LAS II scores. Column I contains the results of the test for equal variance. After LAS II scores reported for both districts were tested to determine equal variance, the variances were found to be the same, indicating it was necessary to use the Type I t-Test. column II indicates that the Type I t-Test was used. Column III reveals the Type I $t-$ Test confirmed a difference between the scores, with $\underline{z}=2.25$ being clearly outside the $(-1.96,1.96)$ acceptance region. Therefore, the second hypothesis was rejected. Column IV shows that District A had significantly higher LAS II scores 
than District $B$. Thus, while District $A$ had higher performance on oral measures, District $B$ outperformed it on reading comprehension.

Performance variation II. Comparison of the mean CTBS reading comprehension scores of the two districts, (District A's LAS-Group and District B) appears on Table 6. Column I contains the result of the test for equal variance of CTBS performance. After CTBS scores reported for both districts were tested to determine equal variance, it was found that the variances were not the same, indicating it was necessary to use the Type II t-test. Column II indicates the use of the Type II t-test. Column III reveals that the Type II t-test confirmed a difference between the scores, with $\underline{z}=2.17$ and being outside the $(-1.96,1.96)$ acceptance region. Therefore, the conclusion was that District $B$ had a significantly higher mean CTBS reading comprehension score than District A's LASGroup. This is indicated in Column IV.

\section{Discussion}

In this study two hypotheses were tested. The first hypothesis was that there is no significant difference in English reading comprehension NCE scores of Spanish-speaking LEP students in an early-exit TBE program and similar students in a late-exit TBE program. This hypothesis was rejected. The scores from District $A$ and District $B$ were first tested 
Table 6

Performance Variation II.

\begin{tabular}{lcccc}
\hline $\begin{array}{c}\text { Test } \\
\text { Used }\end{array}$ & $\begin{array}{c}\text { Variances } \\
\text { Same? }\end{array}$ & $\begin{array}{c}\text { II. } \\
\text { Used } \\
\text { Used }\end{array}$ & $\begin{array}{c}\text { III. } \\
\text { Accept } \\
\text { or } \\
\text { Reject }\end{array}$ & Conclusion \\
\hline CTBS & No & II & $\underline{\underline{z}=} \begin{array}{l}2.17 \\
\text { Reject }\end{array}$ & $\begin{array}{l}\text { District B } \\
\text { Significanty } \\
\text { Better }\end{array}$ \\
\hline
\end{tabular}


for equal variance. The variance was found not to be the same. This resulted in the use of the Type II t-Test to compare scores. After comparison, it was found that the scores were significantly different at the $\mathrm{p}<0.05$ level (Table 5). This leads to the conclusion that District $\mathbb{D}$ students obtained significantly higher scores than District A. Therefore the first hypothesis was rejected.

The second hypothesis tested by this study was that there is not a significant difference in English oral language production scores of Spanish-speaking LEP students in an early-exit TBE program and similar students in a late-exit TBE program. This hypothesis was also rejected. The scores from District $A$ and District $B$ were first tested for equal variance. The variances were equal. This resulted in the use of the Type I t-Test to compare scores. After a comparison, it was found that the scores were significant at the $p<0.05$ level (Table 5). This leads to the conciusion that there is a significant difference between the district scores for English oral language production. District A's scores were found to be significantly higher than District B's scores. Therefore, this second hypothesis was also rejected.

Thus, students participating in the late-exit TBE program in District $B$ attain significantly higher English reading comprehension scores compared to students participating in District A's early-exit TBE program. Overall, District B's 
reading comprehension scores were found to be higher than District A's scores.

students participating in District A's early-exit TBE program attain significantly higher English oral language production scores compared to students from District B's lateexit TBE program. Overall, District A's oral language production scores were found to be higher than District B's scores.

In terms of achievement, there was a significant difference between the districts' reading comprehension scores. The late-exit TBE program showed higher English reading comprehension scores. This finding is consistent with current results reported on student performance in transitional bilingual education programs. Ramirez, Yuen, and Ramey (1991), conducted an eight-year longitudinal study from 198384 to 1990-91 and obtained similar results. In this study immersion strategy, early-exit and late-exit TBE programs were compared for similarities and differences. One of the findings was that LEP students can be provided with substantial amounts of primary language instruction without impeding their acquisition of English language reading skills. This provides opportunity to develop a meaningful and stronger knowledge and language base which facilitates transfer of concepts learned in II to I2 as English language proficiency increases. This accumulation of knowledge and skills 
facilitates the development of the student's cognitive academic language proficiency (CALP) (Cummins, 1989) in L2 which is frequently tested in reading achievement tests.

In terms of English oral language development, there was a significant difference between the districts' oral language production scores. The early-exit TBE program in District $A$ showed higher English oral language production scores. The early exit from the language program increases exposure to English leading to higher scores on measures of language development, but it reduces the opportunity for the development of advanced skills necessary for optimal performance on measures of reading comprehension.

Another finding of this study arose from the comparison of a small group's mean LAS score (District A, with scores reported only for 22 students) with a larger group's mean LAS score (District $B$, with scores reported for 55 students) (Table 1). The statistical test (Type I t-test) performed on this data comparison took into account the difference in size of groups being compared. The statistical findings revealed rejection of the hypothesis, with District $A$ having a significantly higher mean LAS score, at the $\underline{z}=2.25$ level. This score $(\underline{z}=2.25)$ is clearly out of the $(-1.96,1.96)$ acceptance region (Table 5). 
However, this occurrence warranted further investigation. An additional comparison was needed. An additional comparison was considered appropriate. This comparison was conducted to find it District $A^{\prime} S$ LAS-Group scores were surpassing District $\mathrm{B}$ scores in reading comprehension as well as oral language production. This analysis compared District A's LAS-Group mean CTBS reading comprehension score with District $B^{\prime} s$. (Table 2). From this comparison, it was found that District B had significantly higher CTBS reading comprehension scores than District $A$. The level of significance was $\underline{z}=2.17$, which is clearly out of the $(-1.96,1.96)$ acceptance region. This sub-group analysis confirmed that District A's LAS-Group students obtained lower reading comprehension scores than District $B$. Therefore, this rejects the concern of the small group (District A's LAS-Group students) outperforming District B students in reading comprehension. This finding is consistent with results reported on student reading performance in late-exit TBE programs (Ramirez, Yuen, and Ramey, 1991). This finding was that late-exit TBE students outperform early-exit TBE students in the area of reading.

Hence, findings from this study suggest that late-exit TBE programs help contribute to the increase of English reading comprehension abilities in spanish-speaking LEP students. Teaching students in their first language for a longer period of time seems to provide students with the 
common underlying proficiency necessary for successful transitioning of academic skills from the first language to English as cummins (1989) suggested. Based on analysis of test scores, this study provides additional evidence to support the view that academic instruction in spanish for Spanish-speaking LEP students results in higher performance scores on measures of English reading comprehension. This apparent contradiction is explained by both Cummins (1989) and Krashen (1981) through their transfer hypothesis. What a person learns meaningfully and fully understands in one language can be accessed and used when the person develops fluency in a second language.

In this study, the early-exit TBE program had minimal instruction of Ll (Spanish) during the school day. This occurrence seems to indicate that the students did not develop strong academic skills in their Ll (Spanish). This was reflected in the findings of this study. The early-exit TBE program students seemed not to achieve the cognitive academic language proficiency (CALP) needed to successfully transition Ll skills to English.

This study also shows that the early-exit TBE program promotes English oral language development as reflected by the scores on the LAS II. This indicates that providing instruction in English at earlier grade levels contributes to better performance on English oral language measures. 
Indications from the scatter graph comparing District A and District B CTBS scores (Table 3), show that the spread of District A scores appear not to follow a Gaussian Curve. Another indication was that a cluster of scores appeared below the 15th percentile. One possible explanation for this occurrence is that the students scoring at this level got off track while bubbling in corresponding answers to questions, therefore indicating unintentional incorrect responses. Another explanation may be that these students chose not to perform to their best ability and therefore bubbled in any response without thoroughly reading the questions. Another explanation could be that these students have developed social English skills, or basic interpersonal communication skills (BICS), and have not yet developed the academic dimension of language that cummins (1989) calls cognitive academic language proficiency (CALP), which is reflected in the language of the CTBS. Thus, students can converse very well in English, but when confronted with abstract academic language tasks, like the CTBS, they do not have the CALP to do well.

Another factor possibly affecting the results of District $A^{\prime}$ 's reading comprehension scores could be because District $A$ has few certified bilingual teachers. However, District $B$ has many certified bilingual teachers. This occurrence could possibly effect the increased rate of District $B^{\prime} s$ student reading comprehension scores. 
Another finding of this study arose from District $B^{\prime} s$ mean CTBS reading comprehension scores (Table 1). District B boys' mean reading comprehension score $(\bar{X}=38.1)$ was higher than District B girls' mean reading comprehension score $(\bar{X}=35.4)$. However, the differences, variances, and sample sizes indicate that this difference in performance is not significant. Regardless, this is a breakdown in traditional research that indicates female students performing better than male students in reading abilities at this age level. A possible explanation could be that the female students have a lack of interest in being tested. This could possibly explain why District A boys' obtained higher oral language production scores than girls in District $A$, and District B boys obtained higher oral language production scores than girls in District B (Table 1).

Indications from the scatter graph comparing District A and District B LAS II scores (Table 4) show that the spread of District A scores do not exhibit a Gaussian Curve, but District B scores do follow this type of curve. A possible explanation for this occurrence may be because of the smaller number of participants from District $A$ in this section of the study. The reason District A had only 22 scores as compared to District B's 57 (Table 1) was due to one major factor. When District A's LAS II scores were collected from students who met the study's criteria for participation, only 22 
students from District A had LAS II scores from the 1991-92 school year. The other qualifying students from District $A$ had LAS II scores, but these scores were not from the 1991-92 school year. Therefore, those students who had old LAS II scores failed to meet all the criteria of this study and their scores were not used, thus reaucing the size of District A's scores available for this study. This could possibly be an explanation of why District $A^{\prime}$ 's oral language production scores seem not to exhibit a Gaussian Curve.

This study found that while there were significant differences between the reading-comprehension scores across districts, the average scores for both districts were below the 50th percentile (Table 1). This indicates that students' scores are below the national average of students of the same grade level.

The performance at this level could be the result of several factors acting individually, ox in combination. There could be a discrepancy between the skills taught through the local curriculum and those tested in the CTBS. Another possibility could be initial mismatch between the curriculum and the learners' needs. Still another explanation for the low test scores, could be low expectations of instructional personnel. Spanish-speaking children are frequently the victims of differential treatment on the part of educators. A number of studies indicate that Spanish speaking and other 
language minority group members are perceived as low achievers, and low achievers commonly experience a different kind of interaction with school personnel than majority group children who are characterized as high achievers (CDE, 1982). Once a group has been classified according to perceived low status, it is treated in accordance with expectations held for that status (Ogbu, 1978). Members of groups with perceived high status receive qualitatively and quantitatively different types of interactions. Thus, differential treatment may contribute to differential outcomes (CDE, 1982). 
CHAPTER V

Conclusions and Recommendations

\section{Introduction}

The primary aim of this study was to compare the Englishreading comprehension and oral-language production performance of Spanish-speaking, LEP students in an early-exit Transitional Bilingual Education (TBE) Program with those of similar students in a late-exit TBE Program. The findings of this study indicate that English reading comprehension scores of students in a late-exit (TBE) Program were significantly higher than those of an early-exit TBE program. In addition, English oral language production scores of students in the early-exit TBE Program were significantly higher than scores of students in the late-exit TBE Program.

\section{Conclusions}

A number of conclusions may be drawn from the data of this study. The overall assumption of many educators that Spanish-speaking students participating in late-exit TBE programs acquire less English reading comprehension than students in an early-exit TBE program is challenged by the results of this study. The direction of the difference of reading comprehension scores in this study indicates that students from late-exit TBE programs have an advantage with English reading comprehension skills when compared to 
counterparts from early-exit TBE programs. However, results of language score comparisons between the two programs indicate that while early-exit TBE program students have lower English reading comprehension scores, the early-exit TBE program produced significant English oral language production scores. This suggests that greater exposure to English at earlier grade levels may contribute to stronger English oral language production skills. Thus, the evidence supports Cummins (1989) theory that exposure to English leads to higher levels of social language development (BICS), but not necessarily to higher levels of academic language (CALP).

Maintaining Spanish as the primary language of instruction in school does not seem to have detrimental effects on the acquisition of English reading comprehension skills for Spanish-speaking students. In fact, the evidence generally shows that use of Spanish for instruction actually fosters improved English reading comprehension skills. As students are introduced to English, they begin to transfer skills acquired through L1 to situations where they have to use L2 (Cummins, 1989).

Spanish-speaking students participating in late-exit TBE programs seem to be exposed to less English at earlier grade levels than students in early-exit TBE programs, according to the local program design. This amount of exposure could be a factor that affects the achievement rate of English oral 
language production skills of the late-exit TBE program students. In comparison, early-exit TBE program students benefit from increased exposure to English, attaining higher levels of oral language development, but remaining low in reading comprehension abilities as measured through the standardized tests selected.

Finally, this study also suggests that participation in late-exit TBE programs may for a variety of linguistic and pedagogical reasons, be a positive influence on the general school achievement of spanish-speaking students.

\section{Recommendations}

In light of the findings of this study, the following recommendations are proposed:

There is need for research to develop and study procedures for a broader evaluation of the linguistic and academic skills of Spanish-speaking students learning English as a second language. Additional evaluative instruments, other than current ones, that reliably and validly measure intellectual and academic capacities are needed if student performance in bilingual programs is to be thoroughly appraised.

The investigator recommends that to avoid improper interpretation of academic achievement scores when using the standardized achievement tests, it may be more accurate to 
state that what is being measured by those tests is the English to Spanish-speaking students, it may be more accurate to state that what is being measured by those tests is the English conversational level not the academic competence of Spanish-speaking students in the English-speaking classroom at the time the test was taken.

It is recommended that Spanish and English be used as languages of instruction with Spanish-speaking LEP students in the elementary schools. Results from this study indicate that sustained instruction in Spanish, while developing English skills, does contribute to greater English reading comprehension abilities, and does not interfere with the learning process.

It is recommended that English as a second language instruction be continued to promote greater English speaking abilities in Spanish-speaking students, especially those in late-exit TBE programs. Of special concern would be the monitoring of the content and the instructional approaches of the ESL program.

The district with the late-exit TBE program (District B) could review the current English as a second language program to see if it leads to greater development of English oral language production among its' students.

The district with the early-exit TBE program (District A) could review its' policy of transitioning students to 
English-only programs before the student's cognitive academic language proficiency (CALP) is developed to a level that allows productive transitioning. That planning should address development of advanced English language skills which enhance the students' capability to profit from instruction through complex and abstract levels of English.

It is recommended that District B study the unexpected differential performance of boys in reading comprehension. It is also suggested that District $B$ review its school personnel's student expectations. As evidenced by this study, boys are performing better than girls at an age level where girls usually outperform boys. If this reversed trend continues throughout their educational careers, boys' scores may continue to increase while girls' scores remain the same or fall. This reversed trend may suggest that perhaps boys' and girls' scores will not even out as they progress through school, as usually occurs. 
REFERENCES

Arsenian, S. (1937). Bilingualism and mental development. New York: Columila University Press.

Baker, C. (1990). The effectiveness of bilingual education. Journal of Multilingual and Multicultural Development, $\underline{4}$, 269-277.

Baker, C. (1993). Foundations of bilingual education and bilingualism. Philadelphia: Multilingual Matters Limited.

Brown, R. W. (1973) - A first language: The early stages. Cambridge, MA: Harvard University Press. California Department of Education. (1982). Basic principles for the education of language minority students: An Overview. Sacramento: Office of Bilingual-Bicultural Education. California Department of Education. (1988). Coordinated compliance monitoring review (CCMR) manual 1988-89. Sacramento: California Department of Education.

California Department of Education. (1990). Districts ranked by enrollment of LEP students, spring 1990, all languages combined. (Report No. 90-5A) Sacramento: California Department of Education-Bilingual Education office.

California Department of Education. (1991). Option 1 alternatives: Technical standards and recommended practices of development of outcome based assessment of district services to Limited English Proficient (LEP) students. Sacramento: California Department of Education.

California Department of Education. (1992a). Bilingual education outreach, 3,17 . Sacramento: California Department of Education-Bilingual Education office.

California Department of Education. (1992b). "It's elementary!" task force report. Sacramento: California Department of Education.

Carter, T.P., \& Chatfield, M.L. (1986). Effective bilingual schools: Implications for policy and practice. American Journal of Education, 25, 200-232. 
Chamot, A. (1981). Learning English as a second language in a bilingual setting: A guide for parents and teachers. In W. Lambert (Ed.), Faces and facets of bilingualism. Bilingual education series: 10 papers in applied linquistics (pp.14-23). Baltimore, MD: Center for Applied Linguistics.

Collier, V.P. (1987). Age and rate of acquisition of second language for academic purposes. TESOL Quarterly, 21, 617641 .

Collier, V.P., \& Thomas, W.P. (1988, April). Acquisition of cognitive-academic second language proficiency: A six-year study. Paper presented at the American Educational Research Association, New orleans, LA. CTB/McGraw-Hill. (1984). Comprehensive tests of basic skills: Forms U and V (Technical Report). Monterey, CA.

Cummins, J. (1981). Age on arrival and immigrant second language learning in Canada: A reassessment. Applied Linguistics, $\underline{2}, 132-149$.

Cummins, J. (1984). Bilingualism and special education: Issues in assessment and pedagogy. Clevedon, England: Multilingual Matters. Co-published in the United states by College-Hill Press, San Diego.

Cummins, J. (1989). Empowering minority students. Sacramento: California Association for Bilingual Education.

Cziko, G.A. (1992). The evaluation of bilingual education. From necessity and probability to possibility. Educational Researcher, $2,10-15$.

Duncan, S.E., \& DeAvila, E.A. (1978). Language Assessment Scales II. Linguametrics Group.

Edelsky, C. (1989). Putting language variation to work for you. In P. Rigg and V.G. Allen (Eds.), when they don't all speak English (pp. 96-107). Urbana, IL: National Council of Teachers of English.

Edelsky, C., Altwerger, B. \& Flores, B. (1991). Whole language: What's the difference. Portsmouth, NH: Heinemann. 
Franklin, E.A. (1989). Encouraging and understanding the written works of second language children. In P. Rigg and V.G. Allen (Eds.), When they don't all speak English (pp. 77-95). Urbana, IL: National Council of Teachers of English.

Frost, J.I., \& Rowland, G.T. (1970). Developing communication skills. The disadvantaged child. Boston: Houghton Mifflin Co.

Garcia, E. (1991). Instructional discourse in effective Hispanic classrooms. In R. Jacobson and C. Faltis (Eds.), Language distribution issues in bilingual schooling (pp. 104-117). Philadelphia: Multilingual Matters Limited.

Hakuta, K. (1986). Mirror of language: The debate on bilingualism. New York: Basic Books Incorporated.

Hogg, R.V., \& Tanis, E.A. (1977; . Probability and statistical inference. New York: MacMillan Publishing.

John, V.P., \& Horner, V.M. (1971). Early childhood bilingual education. New York: The Modern Language Association of America.

Kagan, S. D. (1986). Cooperative learning and sociocultural factors in schooling. In California Department of Education, Beyond language: Social and cultural factors in schooling language minority students (pp. 231-298). Los Angeles: Evaluation, Dissemination, and Assessment Center, California state University.

Krashen, S.D. (1981). Bilingual education and second language acquisition theory. In California Department of Education (Ed.), Schooling and language minority students: A theoretical framework (pp. 51-79). Los Angeles, CA: Evaluation, Dissemination and Assessment Center, California State University.

Lambert, W. (1981, January). Bilingualism and language acquisition. Paper Presented to New York Academy of Sciences, New York, NY.

Lessow-Hurley, J. (1990). The foundations of dual language instruction. New York: Longman. 
Lucas, T., Henze, R., \& Donato, R. (1990). Promoting the success of Latino language-minority students: An exploratory study of six high schools. Harvard Educational Review, 3 , pp. 315-340.

Milk, R.D. (1990). Integrating language and content: Implications for language distributions in bilingual classrooms. In R. Jacobson and C. Faltis (Eds.), Language distribution issues in bilingual schooling (pp. 32-44). Philadelphia: Multilingual Matters. Iimited.

Mclaughlin, B. (1983). Second language learning: An information-processing perspective. Language Learning, 33, 135-158.

Mitchell, J.V. (Ed.) (1985). Language Assessment Scales II. In The Ninth Mental Measurements Yearbook; Volume I. (pp. 808-811) Buros Institute of Mental Measurements of the University of Nebraska-Lincoln.

Ogbu, J. (1978). Minority education and caste: The American system in cross-cultural perspective. New York: Academic Press.

Peregoy, S.F., \& Boyle, O.F. (1990). Reading and writing scaffolds: Supporting literacy for second language learners. Journal of Educational Issues of Language Minority students, $\underline{6}$, pp. 54-67.

Ramirez, J.D., \& Merino, B.J. (1990). Classroom talk in English immersion, early-exit and late-exit transitional bilingual education programs. In R. Jacobson and C. Faltis (Eds.), Language distribution issues in bilingual schooling (pp. 61-103). Philadelphia: Multilingual Matters Limited.

Ramirez, J.D., Yuen, S.D., \& Ramey, D.R. (1991) . Final report: Longitudinal study of structured English immersion strategy, early-exit and late-exit transitional bilingual education programs for language minority children. Report submitted to the US Depariment of Education. San Mateo, $C A$ : Aguirre International.

Rigg, P. (1989). Language experience approach: Reading naturally. In P. Rigg and V.G. Allen (Eds.) When they don't all speak English (pp. 65-76). Urbana, Il: National Council of Teachers of English. 
Rutter, M. (1983). School effects on pupil progress: Research findings and policy implications. Child Development, 54, 1-29.

Saville, M.R., \& Troike, R.C. (1971). A handbook of bilingual education. Washington, D.C.: TESOL.

Saville-Troike, M. (1976). Foundations for teaching English as a second language: Theory and method for multicultural education. Englewood Cliffs, NJ: Prentice-Hall.

Saville-Troike, M. (1983). Teaching and testing both communicative and academic skills in English as a second language.

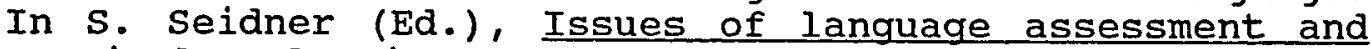
curriculum planning (pp. 137-142). Evanston, IL: Illinois state Board of Education.

Schaefer, R.L. (1989). The student edition of ministatistical software adapted for education [Computer program]. Menlo Park, CA: Addison Wesley.

Skutnabb-Kangas, T. (1979) = Language in the process of cultural assimilation and structural incorporation of linguistic minorities. Rosslyn, VA: National Clearinghouse for Bilingual Education.

Smith, F. (1988). Understanding reading. Hillsdale, NJ: Lawrence Erlbaum Associates Incorporated.

Tikunoff, W.J. (1983). Five significant bilingual instructional features. In W.J. Tikunoff (Ed.), Compatibility of the SBIF features with other research on the instruction Ior LEP siudents (pp.5-18). San Francisco: Far West Laboratory.

Toukomaa, P. \& Skutnabb-Kangas, T. (1977). The intensive teaching of the mother tongue to migrant children of preschool age (Rep. no. 26). UNESCO; University of Tampere: Research.

Tucker, G.R. (1977) . Bilingual education: The linguistic perspective. Arlington, VA: Center for Applied Linguistics.

Wells, G. (1986). The meaning makers: Children learning lanquage and using language to learn. Portsmouth, NH: Heinemann. 
Williams, J.D., \& Snipper, G. (1990). Literacy and bilingualism. White Plains, NY: Longman.

Wong-Fillmore, L. (1982). Instructional language as Iinguistic input: second language learning in classrooms. In L.C. Wilkinson (Ed.) Communicating in the classroom (pp. 115-129). New York: Academic Press.

Wong-Fillmore, L. (1983). Locating learning: The social contexts of second language acquisition. The social contexts of learning in bilingual classrooms (Final Report). Berkeley: University of California, Graduate School of Education.

Wong-Fillmore, L. (1985). Second language learning in children: A proposed model. In National clearinghouse for Bilingual Education (Ed.), Issues in English language development (pp. 33-42). Rosslyn, VA: National clearinghouse for Bilingual Education. 